DOI: https://doi.org/10.15407/techned2019.06.013

\title{
SHIELDING OF UNDERGROUND EXTRA-HIGH VOLTAGE CABLE LINE BY PLANE FERROMAGNETIC SHIELD
}

$\quad$ Journal
Publisher
ISSN
Issue
Pages

\author{
Tekhnichna elektrodynamika \\ Institute of Electrodynamics National Academy of Science of Ukraine \\ 1607-7970 (print), 2218-1903 (online) \\ No 6, 2019 (November/December) \\ $13-17$
}

\begin{abstract}
Author
Kucheriava I.M.

Institute of Electrodynamics National Academy of Sciences of Ukraine, pr. Peremohy, 56, Kyiv, 03057, Ukraine, e-mail: rb.irinan@gmail.com
\end{abstract}

\begin{abstract}
The computer modeling by finite-element method is used to study the features of magnetic field distribution around the underground single-circuit three-phase $330 \mathrm{kV}$ cable line with polyethylene insulation when using a flat ferromagnetic shield. In the developed model, the three-phase currents running in cable conductors along with the currents induced in cable metallic shields are taken into account. The open-shield configuration is considered. The shield is made of the ferromagnetic hot-rolled low-carbon material Magnetil with specified electrophysical properties. The computed distributions of the magnetic field established by the cable line are obtained and discussed. The magnetic field level depending on the depth of the shield in the ground, the dimensions of the shield (including its width and thickness), the magnetic permeability of shield material as a function of magnetic flux density are analyzed. Ref erences 10 , figures 5 .
\end{abstract}

Key words: underground three-phase cable line, ferromagnetic screen, magnetic field, computer simulation. 
Received: 21.02.2019

Accepted: 26.02 .2019

Published: 25.10.2019

\section{References}

1. Doronin M.V., Greshniakov G.V., Korovkin N.V. Magnetic shields of special design. Nauchno -tekhni-cheskie vedomosti Sankt-Peterburgskogo politekhnicheskogo universiteta. 2017

. Vol. 23. No 1. Pp. 124-133. DOI:

https://doi.org/10.18721/ JEST.230112

(Rus)

2. Machado V.M. Magnetic field mitigation shielding of underground power cables. IEEE

Transactions on Magnetics

. 2012. Vol. 48. No 2. Pp. 707-710.

DOI:

https://doi.org/10.1109/TMAG.2011.2174775

3. Kucheriava I.M. Magnetic field of extra-high voltage two-circuit cable line with XLPE insulation. Pratsi Instytutu Elektrodynamiki NAN Ukrainy. 2019. Is. 52. Pp. 13-17. (Rus) DOI: $\underline{h}$ ttps://doi.org/10.15407/publishing2019.52.013

4. D'Amore M., Menghi E., Sarto M.S. Shielding techniques of the low-frequency magnetic field from cable power lines. IEEE Internat. Symposium on Electromagnetic Compatibility. 18-22

Aug., 2003. Istanbul. 2003. Vol. 1. Pp. 203-208.

5. De Wulf M., Wouters P., Sergeant P., Dupré L., Hoferlin E., Jacobs S., Harlet P.

Electromagnetic shielding of high-voltage cables. Journal of Magnetism and Magnetic Materials . 2007. No 316. Pp. 908-911. DOI:

https://doi.org/10.1016/j.jmmm.2007.03.137

6. Shcherba A.A., Podoltsev O.D., Kucheriava I.M. The magnetic field of underground $330 \mathrm{kV}$ cable line and ways for its reduction. Tekhnichna Elektrodynamika. 2019. No 5. Pp. 3 - 9. (Rus) DOI:

https://doi.org/10.1540

7/techned2019.05.003

7. Comsol multiphysics modeling and simulation software. URL: http://www.comsol.com/

8. Podoltsev A.D., Kucheriava I.M. Multiscale modeling in electrical engineering. Kyiv: Instytut Elektrodynamiky NAN Ukrainy, 2011. 255 p. (Rus)

9. Lyach V.V., Molchanov V.M., Santatskii V.G., Kvitsinskii A.A. 330 kV cable line: some aspects of de-signing. Promelektro. 2009. No 6. Pp. 27-33. (Rus)

10. Electric installation code. Minpalyvenerho Ukrainy, 2010. 776 p. (Ukr) 
